\title{
ANALISIS PERKEMBANGAN EKSTRAKURIKULER FUTSAL DITINGKAT SMP NEGERI KOTA BENGKULU
}

\author{
Tri Rahmadianti \\ Program Studi Pendidikan Jasmani FKIP Universitas Bengkulu \\ Email : triir36@gmail.com \\ Tono Sugihartono \\ Universitas Bengkulu \\ Ari Sutisyana \\ Universitas Bengkulu
}

\begin{abstract}
Abstrak
Penelitian ini bertujuan untuk mengetahui perkembangan ekstrakurikuler futsal. Metode yang digunakan adalah metode penelitian deskriptif. Subjek penelitian adalah 9 SMP Negeri di Kota Bengkulu. Instrumen penelitian ini adalah Observasi, Angket, dan Dokumentasi. Hasil penelitian menunjukkan bahwa persentase perkembangan futsal ekstrakurikuler di SMP Negeri Bengkulu berkembang 6 sekolah 66,66\%, belum berkembang 3 sekolah 33,33\%. Setelah mendapatkan persentase data maka dapat dilakukan perbandingan perkembangan ekstrakurikuler futsal di SMP Negeri Kota Bengkulu tingkat bengkulu 6:3. Berdasarkan perolehan data perkembangan ekstrakurikuler futsal di Sekolah Menengah Pertama Negeri Bengkulu harus memperhatikan indikator yang baik seperti peran siswa, pelatih yang kompeten, manajemen yang baik, fasilitas, metode pelatihan. Jadi hasil data yang diperoleh dari sembilan sekolah ada 6 sekolah yang memiliki indikator baik. Sementara 3 sekolah belum terlihat perkembangan indikator yang belum memenuhi proses mendukung pengembangan futsal ekstrakurikuler.
\end{abstract}

Kata Kunci : Perkembangan, Ekstrakurikuler, Futsal

\begin{abstract}
This study aims to determine the development of futsal extracurricular activities. The method used is descriptive research method. The research subjects were 9 Middle Schools in the City of Bengkulu. The instruments of this study are Observation, Questionnaire, and Documentation. The results showed that the percentage of extracurricular futsal development in Bengkulu State Middle School grew by 6 schools $66.66 \%$, not yet developed 3 schools 33.33\%. After getting the percentage of data, we can compare the development of futsal extracurricular activities at Bengkulu City State
\end{abstract}


Middle School bengkulu level 6: 3. Based on data obtained from the development of futsal extracurricular activities in Bengkulu State Junior High School, it must pay attention to good indicators such as competent students, good management facilities, training methods. So the results of data obtained from nine schools have 6 schools that have good indicators. While 3 schools stated that there were no developments in indicators that had not met the process of supporting the development of extracurricular futsal.

Keywords: Development, Extracurricular, Futsal

\section{PENDAHULUAN}

Olahraga merupakan salah satu aktivitas jasmani dan rohani yang dilakukan oleh perorangan maupun kelompok. Olahraga telah menjadi rutinitas sehari-hari dan Olahraga mempunyai peranan penting dalam kehidupan manusia. Dalam kehidupan modern sekarang ini manusia tidak bisa dipisahkan dari kegiatan-kegiatan olahraga. Dengan berkembangnya zaman, pada saat ini cabang olahraga sudah banyak bermunculan, diantaranya futsal.

Menurut Lhaksana Justinus (2011:5) Futsal merupakan salah satu cabang olahraga permainan yang cukup populer di Indonesia. Futsal masuk ke Indonesia pada Tahun 1998, kemudian pada Tahun 2000-an, futsal mulai dikenal masyarakat. Pada tahun 2002 AFC meminta Indonesia untuk menggelar kejuaraan Piala Asia. Sejak itulah futsal berkembang dengan pesat di Indonesia hingga saat ini. Perkembangan futsal juga berkembang pesat di kalangan sekolah, ini dibuktikan dengan adanya ekstrakurikuler di sekolah-sekolah.

Menurut Charlim (2011:4) bahwa: Futsal adalah suatu jenis olahraga yang memiliki aturan tegas tentang kontak fisik. Sliding tackle (menjegal dari belakang), body charge (benturan badan), dan aspek kekerasan lain seperti dalam permainan sepak bola tidak di izinkan dalam futsal.

Menurut Lhaksana Justinus (2011:29) menyatakan bahwa Permainan futsal mengharuskan para pemainnya diajarkan bermain dengan sirkulasi bola yang sangat cepat, menyerang dan bertahan dan juga sirkulasi permainan tanpa bola ataupun timing yang tepat. Seorang pemain juga harus memiliki fisik, mental dan teknik bermain yang baik.

Teknik dasar yang perlu dikuasai seorang pemain futsal yaitu passing, control, chipping, dribbling dan shooting. Teknik dasar sangatlah penting, karena menunjang performa pemain di lapangan. Adapun yang dijelaskan Lhaksana,Justinus (2011: 7) mengatakan bahwa "siapa yang mencetak gol sama sekali tidak penting, yang penting adalah gol yanh tercetak. menang dan kalah itu terjadi diseluruh olahraga, tetapi if you die, you die with honour".

Kegiatan ekstrakurikuler merupakan kegiatan yang dilaksanakan di luar jam pelajaran formal dan merupakan salah satu upaya pembinaan bagi pelajar. Program ekstrakurikuler 
diperuntukkan bagi siswa yang ingin mengembangkan bakat dan kegemarannya dalam cabang olahraga serta lebih membiasakan hidup sehat (Depdikbud, 2002: 25).

\section{METODE}

Penelitian ini adalah penelitian lapangan yang bersifat deskriptif analisis yang menggunakan pendekatan kualitatif. Deskriptif adalah hanya menggambarkan situasi yang sedang berlangsung, tanpa penguji hipotesis. Metode yang digunakan adalah survey yaitu pengumpulan data dilapangan.

Sugiyono (2006:6) menyatakan bahwa metode survey digunakan untuk mendapatkan data dari tempat tertentu yang alamiah (bukan buatan ), tetapi peneliti melakukan perlakuan dalam pengumpulan data,misalnya dengan mengedarkan kuesioner,tes, wawancara instruktur dan sebagainya. Berdasarkan penjelasan peneliti akan mengambil data di lapangan.

Sesuai dengan permasalahan yang dikaji dalam penelitian ini, maka ditetapkan pembina, pelatih dan siswa sebagai subyek dan obyek penelitian. Mengambil subyek dalam penelitian ini menggunakan teknik purposive, yaitu dengan memilih orang-orang yang dianggap tahu tentang fokus masalah seperti pihak yang terkait dengan pengambilan keputusan seperti pelatih. Kemudian dipadukan dengan teknik snowball sampling, yaitu meminta informan sebelumnya untuk menunjukan orang-orang yang dapat dijadikan informan. Sugiyono (2006: 246).
Penelitian ini mengambil obyek penelitian seluruh yang berhubungan dengan perkembangan ekstrakurikuler futsal di tingkat SMP Negeri Kota Bengkulu. Menurut Sanafiah Faisal dalam Sugiyono (2006: 328) dalam mengambil subyek dan obyek penelitian harus yang memahami dan yang tergolong masih berkecimpung atau terlibat dalam kegiatan yang akan diteliti.

Pujianto dan Insanistyo (2017:71) menjelaskan bahwa pengumpulan data adalah proses pengumpulan informasi melalui intrumen penelitian yang telah disusun atau dipakai oleh peneliti. Menurut Sugiyono (2012:22) teknik pengumpulan data merupakan langkah yang paling utama dalam penelitian, Karena tujuan dari penelitian adalah mendapatkan data.Teknik pengumpulan data dalam Penelitian pengumpulan data adalah Observasi, Kuesioner dan Dokumentasi

1. Observasi untuk pengamatan langsung untuk mengetahui kondisi faktual dari perkembangan ekstrakurikuler futsal.

2. kuesioner ini digunakan karena dinilai lebih efektif dan efisien selain itu juga memudahkan dalam analisis data. Dalam hal ini untuk mengetahui persepsi atau pendapat tentang perkembangan ekstrakurikuler futsal SMP negeri kota bengkulu

3.Dokumentasi tujuan untuk memperoleh data berupa data tertulis,foto,dan gambar untuk kepentingan kevalidan data penelitian,sejumlah besar data dan fakta tersimpan dalam bahan yang berbentuk dokumentasi,sifat utama data ini tidak terbatas pada ruang dan waktu sehingga memberikan peluang 
kepada peneliti untuk mengetahui hal-hal yang pernah terjadi waktu silam.

\section{HASIL DAN PEMBAHASAN}

Penelitian ini dilakukan di SMP Negeri Kota Bengkulu dengan melakukan penelitian menggunakan observasi, kuesioner kepada responden yang berhubungan dengan Perkembangan Ekstrakurikuler Futsal di Tingkat SMP Negeri Kota Bengkulu. Data observasi dapat terlihat jelas dari pandangan ke sembilan SMP Negeri Kota Bengkulu berupa lapangan sebagai wadah latihan, beberapa fasilitas perlengkapan seperti bola, jaring, garis lapangan dan gawang. Kesembilan SMP ini memiliki berbagai prestasi yang diperoleh terlihat dari fasilitas perlengkapan futsalnya. Perkembangan yang diperoleh dari ketiga aspek yaitu pembina ekstrakurikuler futsal, pelatih futsal dan siswa. dikembangkan berdasarkan fokus permasalahan terlihat dari sarana dan prasana, lisensi kepelatihan futsal, dan dukungan dari pihak sekolah.

\section{Perkembangan Ekstrakurikuler Futsal ditingkat SMP Negeri Kota} Bengkulu hampir sama yang didukung dari segi sarana dan prasarana, fasilitas dilapangan sewaktu latihan dan dukungan dari pihak sekolah. Adapun kendala yang menghambat dari perkembangan ekstrakurikuler futsal yang terdapat di sembilan SMP Negeri Kota Bengkulu ini yaitu peran seorang pelatih kurang aktif dalam penerapan latihan yang efektif dan efesien. Ketidak efektifitas seorang pelatih berpengaruh dengan ada atau tidak adanya lisensi kepelatihan yang dimiliki seorang pelatih terkhusus futsal. Data yang diperoleh dari hasil observasi dapat disajikan dengan tabel sebagi berikut:

Data yang disajikan pada bagian ini berupa hasil observasi yang dilakukan melalui pengamatan langsung dengan siswa dan guru olahraga terhadap objek penelitian dengan melalui survey ke tempat yang akan diteliti. Berdasarkan data yang diperoleh dari kegiataan penelitian yang dilaksanakan selama satu bulan peneltian dan 9 sekolah menjadi objek dan data tersebut melibatkan sembilan pembina ekstrakurikuler futsal, sembilan pelatih futsal, 45 siswa ekstrakurikuler futsal, observasi non partisipatif, sarana dan prasarana di SMP Negeri Kota Bengkulu.

Memfokuskan pada hal-hal yang penting, dicari tema dan polanya dan membuang yang tidak perlu, dapat ditarik kesimpulan Perkembangan Ekstrakurikuler Futsal DiTingkat SMP Negeri Kota Bengkulu masih banyak yang perlu diperhatikan oleh Pihak Sekolah terserbut. Seperti Perkembangan Ekstrakurikuler Futsal di setiap Sekolah tidak sama disebabkan banyak faktor yaitu, Pembinaan dari sekolah belum mendukung berjalannya kegiatan ekstrakurikuler futsal, pelatih yang kurang berkompeten terlihat dari lisensi kepelatihan yang diperolehnya, dan ketersediaan fasilitas perlengkapan yang belum sama rata seperti ada yang sudah memiliki lapangan yang baik dan juga ada yang belum memadai, begitu juga dengan ketersediaan bola pada saat latihan.

Ketidak samaan dari segi pembinaan, pelatih dan fasilitas perlengkapan yang membuat semua SMP Negeri Kota Bengkulu memiliki 
perbedaan dari Perkembangan Ekstrakurikuler Futsal tersebut. Hambatan dalam Perkembangan adalah dukungan dari pihak sekolah, pembinaan ekstrakurikuler, dan pelatih ekstrakurikuler futsal. berdasarkan hasil keseluruhan yang mencangkup kajian teori 6 sekolah yang dinyatakan berkembang yaitu SMP NEGERI 18 Kota Bengkulu, SMP NEGERI 12 Kota Bengkulu, SMP NEGERI 2 Kota Bengkulu, SMP NEGERI 1 Kota Bengkulu, SMP NEGERI 4 dan SMP NEGERI 3 Kota Bengkulu. Yang tidak memenuhi komponen-komponen yang mendukung ekstrakurikuler futsal berkembang ada 3 sekolah yaitu SMP NEGERI 6 Kota Bengkulu, SMP NEGERI 17 Kota Bengkulu dan SMP NEGERI 7 Kota Bengkulu.

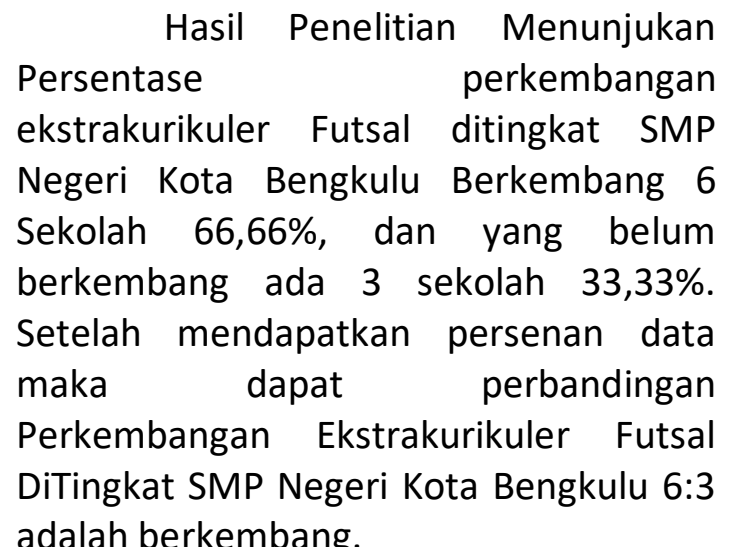
adalah berkembang.

Hasil dari penelitian perkembangan SMP Negeri Kota Bengkulu dapat disimpulkan bahwa ada beberapa faktor yang mempengaruhi berkembang atau tidak berkembangnya perkembangan ekstrakurikuler futsal ditingkat SMP Negeri Kota Bengkulu yaitu :

1. Kurangnya dukungan dari pihak sekolah, sehingga fasilitas perlengkapan untuk kebutuhan pelatih melatih kurang efesien, lapangan yang berlobang dan bola saat latihan kurang menjadikan program latihan tidak maksimal.

2. Pelatih yang tidak memiliki lisensi kepelatihan, serta memiliki perbedaan dari segi prestasi dan pengalaman melatih dengan pelatih yang memiliki lisensi kepelatihan. Sehingga membuat program latihan yang diterapkan kurang baik untuk peningkatan prestasi siswa. Ada yang menerapkan program latihan rutin, pengetahuan teori latihan yang luas, dan dapat mempraktekkan setiap teori yang diberikan. Jika komponen tersebut terpenuhi sangat mempengaruhi berkembangnya futsal disuatu SMP Negeri Kota Bengkulu.

\section{PENUTUP}

\section{Simpulan}

Berdasarkan perolehan data perkembangan ekstrakurikuler futsal ditingkat SMP Negeri Kota Bengkulu harus memperhatikan indikator pelatih, manajemen, fasilitas, metode latihan dan prestasi. Tanpa pelatih yang berkompeten seperti, merancang,

menyusun, melaksanakan dan mengevaluasi proses berlangsungnya latihan perkembangan tidak dapat terbentuk. Adapun peranan dari manajemen yaitu memiliki dukungan yang penuh serta dapat memberikan fasilitas demi menciptakan keaktifan dan kedisiplinan siswa dalam melakukan latihan ekstrakurikuler futsal. berdasarkan hasil data diperoleh dari 9 sekolah ada 6 sekolah yang memiliki indikator yang baik, 
sedangkan 3 sekolah dinyatakan belum ada perkembangan terlihat dari indikator yang belum memenuhi proses menunjangnya perkembangan ekstrakurikuler futsal. Berdasarkan hasil penelitian tersebut dapat disimpulkan bahwa perkembangan 6 sekolah tersebut disebabkan banyak indikator yaitu pembina yang bagus, dukungan dari pihak sekolah, memiliki pelatih yang berkompeten, memiliki fasilitas peralatan yang memadai dan memiliki target yang jelas. Maka dari itu hanya ada 6 sekolah SMP Negeri Kota Bengkulu yang dinyatakan berkembang, sedangkan 3 sekolah SMP Negeri Kota Bengkulu belum bisa dikatakan berkembang disebabkan indikator yang menunjang proses perkembangan masih belum terpenuhi

\section{Saran-saran}

Setelah melakukan penelitian tentang "Analisis perkembangan Ekstrakurikuler Futsal Ditingkat SMP Negeri Kota Bengkulu", maka penulis memberikan saran-saran sebagai berikut:

1. Sebaiknya setiap pelatih dari semua SMP Negeri Kota Bengkulu pernah mengikuti kepelatihan futsal, karena mempengaruhi kualitas latihan yang diberikan pada siswa.

2. Perlunya dukungan penuh dari pihak sekolah sehingga fasilitas perlengkapan latihan pada ekstrakurikuler futsal ditingkat SMP Negeri Kota Bengkulu memadai
3. Sebaiknya sarana dan prasarana menjadi perhatian utama dalam ekstrakurikuler futsal, karena sangat mempengaruhi perkembangan atau tidaknya ekstrakurikuler futsal yang ada di SMP Negeri Kota Bengkulu.

4. Metode latihan yang baik sangat dibutuhkan siswa pada saat latihan, maka diperlukan pelatih yang berkualitas yang mengerti metode pada saat latihan.

5. Untuk mencapai prestasi yang optimal diperlukan suatu rencana matang yang dituangkan ke dalam program latihan, dari situlah hasil yang maksimal akan tercapai.

\section{DAFTAR PUSTAKA}

Anwar, Dessy. 2003. Kamus Lengkap Bahasa Indonesia. Surabaya: Amelia Surabaya.

Charlim, dkk. 2011. Mengenal Lebih Jauh Tentang Futsal . Jakarta: Multi Kreasi Satudelapan.

Ekkry, Yarmani, Santun, dan Defliyanto. 2018. "Pengaruh Metode Latihan Teknik Distribusi Terhadap Keterampilan Dribbling Zig Zag Permainan Futsal". Jurnal Kinestetik, Vol. 2 (2).

Lhaksana \& Pardosi Iskhak. 2008. Inspirasi dan Spirit Futsal. Jakarta: Raih Asa Sukses 
Lhaksana, Justinus. 2011. Taktik dan Strategy Futsal Modern. Jakarta

Mulyono, Muhammad Asriady. 2014. Buku Pintar Panduan Futsal.Banda Aceh: Laskar Aksara.

Tenang, Jhon D. 2008. Mahir bermain futsal. Jakarta : Dar Mizan.

Roni Nasrudin. 2010. pengaruh partisipasi siswa dalam kegiatan ekstrakurikuler terhadap motif berprestasi siswa SMK N 2 Garut. Skripsi: UPI Bandung.

Sugiyono. 2006. memahami penelitian kualitatif.Bandung: Alfabeta

Pamungkas, Yoga D.S. 2013. tingkat keterampilan teknik dasar bermain futsal peserta ekstrakurikuler futsal SMA dan SMK Yayasan PIRI Daerah Istimewa Yogyakarta. Yogyakarta: Universitas Negeri Yogyakarta

Prastya, Rizki Dwi. 2005. Manajemen ekstrakurikuler futsal SMA Negeri 4 Yogyakarta Tahun Ajaran 2015. Yogjakarta: Universitas Negeri yogjakarta

Handoyo.A. 2010. Bermain Fustal. Jakarta: Nobel Edumedi
Arikunto S, 1989, Prosedur pendekatan praktis jakarta. PT Reneka cipta

Mulyono, Muhamad Asriady. 2017. Buku Pintar Futsal.Jakarta, Anugrah

Syarifudin, 1996:24, Tugas dan tanggung jawab pelatih. Jakarta. PT Reneka Cipta.

Sugiyanto , Bogy, dan Defliyanto. 2019. "Implementasi Metode Rondo Untuk Meningkatkan Teknik Passing Mahasiswa Pada Mata Kuliah Futsal Penjas Prodi Penjas FKIP UNIB". Jurnal Kinestetik, Vol. 3 (1).

Yudianto, Lukman. 2009. Teknik Bermain Sepakbola dan Futsal. Visi 7

Pate, R 2009.Pengolahan Pusat Pendidikan dan Latihan Olahraga. Jawa Timur Asisten Deputi IPTEK Olahraga. 